\title{
Efektivitas Penambahan Seng dan Vitamin A pada Pengobatan Anemia Defisiensi Besi
}

\author{
Franciska Louise Kaihatu, Max Mantik \\ Bagian Ilmu Kesehatan Anak FK UNSRAT. RSU Prof. Dr. R. D. Kandou Manado
}

\begin{abstract}
Latar Belakang. Prevalensi anemia defisiensi besi (ADB) masih tinggi di Indonesia. Prinsip tata laksana anemia adalah mencari penyebab, mengatasinya, memberikan terapi besi dan pencegahan. Beberapa zat berinteraksi baik dengan besi. Interaksi antara besi dan seng dan besi dengan vitamin A telah terbukti pengaruhnya terhadap anemia.

Tujuan. Untuk mengetahui apakah pemberian besi + seng + vitamin A pada ADB lebih efektif meningkatkan kadar $\mathrm{Hb}$ dan retikulosit dibandingkan besi saja.

Metode. Menggunakan pretest and posttest control group design secara tersamar tunggal pada anak usia 5-11 tahun dengan ADB di beberapa panti asuhan di Manado dari Desember 2006-Maret 2007. Dibagi atas dua kelompok Kelompok I mendapat besi + vitamin A + seng dan kelompok II mendapat besi dan plasebo. Hasil. Perbandingan kadar Hb setelah terapi antar ke-2 kelompok didapatkan perbedaan bermakna $(p<0,01)$, namun tidak pada kadar retikulosit $(p>0,05)$.

Kesimpulan. Pemberian besi + vitamin A + seng efektif meningkatkan kadar Hb dibandingkan besi saja.(Sari Pediatri 2008;10(1):24-28).
\end{abstract}

Kata Kunci: ADB, seng, vitamin A, hemoglobin, retikulosit

1

nemia defisiensi besi lebih sering ditemukan di negara yang sedang berkembang. Hal ini disebabkan oleh kemampuan ekonomi yang terbatas, konsumsi protein hewani yang rendah, serta makanan pokoknya berupa padipadian/biji-bijian (tumbuhan) yang rendah kandungan

Alamat Korespondensi:

Prof. Dr. Max F.J.Mantik, SpA(K). Bagian Ilmu Kesehatan Anak FK. Unsrat/RSU Prof.Dr. R.D. Kandou, Manado Telp: 0431-821652; Fax:0431-85909 Email: ikarsup@telkom.net besinya dan kaya akan asam fitat dan serat yang dapat menghambat penyerapan besi. ${ }^{1,2,3}$ Di Indonesia prevalensi anemia defisiensi besi masih sangat tinggi terutama pada wanita hamil, anak balita, usia sekolah, dan pekerja berpenghasilan rendah. ${ }^{1,4}$

Prinsip tata laksana anemia defisiensi besi adalah mengetahui faktor penyebab dan mengatasinya serta memberikan terapi penggantian dengan preparat besi. Terdapat beberapa zat yang berinteraksi baik dengan besi namun ada juga beberapa zat yang tidak berinteraksi baik dengan besi. ${ }^{1,5,6}$ Interaksi antara besi dan seng dan antara besi dan vitamin A telah 
dibuktikan kebenarannya mempengaruhi kesembuhan dari anemia pada tingkat metabolik. ${ }^{7}$

Seng dianggap meningkatkan konsentrasi vitamin A melalui produksi retinol banding protein (RBP) dan mekanisme langsungnya pada anemia. Bagaimana seng mempengaruhi metabolisme besi belum dapat dijelaskan dengan pasti, tetapi 3 mekanisme yang mungkin berdasarkan peran fisiologis dan biokimianya yaitu modulasi eritropoeisis, imunitas, dan modulasi metabolisme besi. ${ }^{7-10}$ Terdapat sedikit informasi tentang efek seng pada besi kecuali untuk interaksi antara seng dan besi pada tempat/reseptor penyerapan yang sama pada sel-sel mukosa usus atau interaksi absorbsi yang mungkin terjadi selama metabolisme. Dosis seng yang tinggi dapat mengganggu absorbsi besi begitu pula sebaliknya. Dengan perbandingan molar besi dan seng $1: 1$, hambatan penyerapan kecil atau tidak ada, sedangkan ratio 2:1 dan 3:1 hambatan penyerapan meningkat. ${ }^{7,11-14}$

Vitamin A mempengaruhi sintesis seng yang terikat pada protein, juga absorbsi dan transport seng, di samping mekanisme langsungnya pada anemia., ${ }^{2,710}$, Kombinasi vitamin A dan besi meningkatkan absorbsi besi dari makanan berbasis padi-padian, meningkatkan mobilisasi besi dari jaringan penyimpanan melalui peningkatan sintesis reseptor, menurunkan pengambilan besi yang berlebihan pada keadaan infeksi, eritropoeisis yang meningkat atau pembentukan kompleks vitamin A besi non-heme yang menahannya tetap dapat larut dalam lumen usus dan mencegah efek yang menghambat inhibitor terhadap absorbsi besi. ${ }^{2,3,15}$

Seng dan vitamin A bekerja secara sinergis dan saling melengkapi sehingga memberikan hasil yang positif terhadap keadaan anemia defisiensi besi.

\section{Metode}

Penelitian menggunakan pretest and posttest control group design secara tersamar tunggal pada beberapa panti asuhan di Manado dari Desember 2006-Maret 2007, pada anak usia 5-11 tahun dengan ADB yang memenuhi kriteria penelitian. Kriteria eksklusi meliputi $\mathrm{ADB}$ berat, penyakit kronis, gizi buruk, obesitas, telah mendapat terapi dengan salah satu preparat tersebut, perdarahan gastrointestinal dan sedang menderita sakit. Pada semua anak yang dicurigai ADB dengan pucat, dilakukan pengambilan darah vena $5 \mathrm{ml}$ oleh petugas laboratorium untuk pemeriksaan darah rutin, retikulosit, SI, TIBC. Sampel darah dikirim dan diperiksa di laboratorium. Selanjutnya pada semua anak yang positif $\mathrm{ADB}$ dilakukan pengambilan tinja untuk pemeriksaan darah samar (tes bensidin) dan telur cacing. Anak menderita cacingan diberi terapi dan tetap diikutsertakan dalam penelitian, sedangkan yang positif darah samar dikeluarkan dari penelitian. Subjek dibagi atas dua kelompok yaitu kelompok I mendapat preparat besi $3-3,75 \mathrm{mg} / \mathrm{kgbb} / \mathrm{hr}$ (dipilih dosis tersebut selain untuk kepraktisan dalam pemberian juga dimaksud agar rasio molar besi dan seng tidak mencapai perbandingan $2: 1$, sehingga diharapkan dapat mengurangi hambatan penyerapan antar keduanya), seng $2 \mathrm{mg} / \mathrm{kgbb} / \mathrm{hr}$, dan vitamin A 200.000 IU. Kelompok II (kontrol) mendapat besi dan placebo. Preparat besi (sulfas ferosus) diberikan setiap hari selama 2 bulan, Vitamin A (soft capsule) satu kali pemberian pada awalnya, seng (seng sulfat) setiap hari selama dua minggu. Kedua kelompok akan di follow up retikulosit pada hari ke 5-10 dan kadar $\mathrm{Hb}$ setelah 2 bulan terapi. Pola menu pada kelima panti asuhan tersebut hampir sama sehingga dianggap sebanding dan tetap dipertahankan seperti itu hingga akhir penelitian.

Data penelitian ini dianalisis dengan analisis statistik deskriptif untuk karakteristik sampel. Uji Wilcoxon signed rank untuk pengujian perbedaan ke-2 kelompok berpasangan dan uji Mann-Whitney untuk pengujian perbedaan kedua kelompok independent (sebab data tidak menyebar normal).

\section{Hasil}

Selama periode penelitian yang dilakukan di lima panti asuhan di Manado yaitu Al-ikhwan, Siti Khadijah, Darusaadah, Arahmah dan Darul-Istiqoma didapatkan anemia defisiensi besi pada 60 anak. Dari 60 anak tersebut, 56 anak memenuhi kriteria penelitian, dan 4 anak tidak diikutsertakan karena hasil bensidin tes positif. Dari 56 anak yang mengikuti penelitian, 4 anak akhirnya dikeluarkan dari penelitian karena 1 anak tidak minum obat teratur, 2 anak tidak ada saat pemeriksaan akhir dan 1 anak telah keluar dari panti asuhan, sehingga di akhir penelitian didapatkan 52 anak (26 kelompok I dan 26 kelompok II). 
Tidak terdapat perbedaan bermakna pada kedua kelompok dalam distribusi jenis kelamin, umur dan status gizi. Pada kelompok I didapatkan gizi kurang 19 anak $(73,1 \%)$ dan kelompok II/kontrol didapatkan gizi kurang 15 anak (57,7 \%). Terdapat kenaikan kadar $\mathrm{Hb}$ yang sangat bermakna sebelum dan sesudah pemberian besi + vitamin $\mathrm{A}+\operatorname{seng}(\mathrm{p}<0,001)$. Hasil ini tertera pada Tabel 1.

Hasil uji perbedaan kadar retikulosit sebelum dan sesudah pemberian besi + vitamin A + seng memperlihatkan kenaikan retikulosit yang sangat bermakna $(p<0,001)$, tertera pada Tabel 2 .

Hasil uji perbedaan kadar $\mathrm{Hb}$ antara kelompok I dan kelompok II secara statistik memperlihatkan perbedaan bermakna $(\mathrm{p}<0,001)$, tertera pada Tabel 3 .

Pada uji perbedaan kadar retikulosit antara kelompok I dan Kelompok II secara statistik tidak didapatkan perbedaan $(\mathrm{p}>0,05)$, tertera pada Tabel 4 .

Tabel 1. Hasil uji perbedaan kadar Hb sebelum dan sesudah pemberian Besi + Vitamin A+ Seng

\begin{tabular}{lrcc}
\hline Pemberian suplemen & Median & z & $p$ \\
\hline Awal & 10.000 & $-4,478$ & $<0,001$ \\
Akhir & 13.550 & & \\
\hline z adalah uji Wilcoxon signed rank & & &
\end{tabular}

Tabel 2. Hasil uji perbedaan kadar retikulosit sebelum dan sesudah pemberian besi + vitamin A+ seng

\begin{tabular}{lccc}
\hline Pemberian suplemen & Median & $z$ & $p$ \\
\hline Awal & 0,950 & & \\
Akhir & 1,050 & $-5,099$ & $<0,001$ \\
\hline
\end{tabular}

$\mathrm{z}$ adalah uji Wilcoxon signed rank

Tabel 3. Uji perbedaan kadar $\mathrm{Hb}$

\begin{tabular}{lccc}
\hline Kelompok & Median & $\mathrm{z}$ & $p$ \\
\hline Besi & 1,70 & $-6,361$ & $<0,001$ \\
Besi + vit A + seng & 3,55 & & \\
\hline z adalah uji Mann-Whitney & & &
\end{tabular}

Tabel 4. Uji perbedaan kadar retikulosit

\begin{tabular}{lccc}
\hline Kelompok & Median & $\mathrm{z}$ & $p$ \\
\hline Besi & 0,10 & \multirow{2}{*}{0,00} & $>0,05$ \\
Besi + vit A + seng & 0,10 & & \\
\hline
\end{tabular}

$\mathrm{z}$ adalah uji Mann-Whitney

\section{Pembahasan}

Sebagian besar status gizi pada kedua kelompok adalah gizi kurang; untuk kelompok besi + vit. $\mathrm{A}+$ seng didapatkan 73,1\% dan kelompok besi 57,7\%. Beberapa penelitian di Indonesia mendapatkan prevalensi kurang gizi usia 5-14 tahun 38\%-67\%. Di negara sedang berkembang, tingginya prevalensi anemia defisiensi besi berkaitan dengan masukan besi yang relatif rendah dan umumnya berhubungan dengan kejadian malnutrisi. ${ }^{1,6,16,17}$

Pada kelompok yang menerima besi + vitamin A + seng, didapatkan peningkatan kadar $\mathrm{Hb}$ sesudah terapi $(\mathrm{p}<0,001)$. Begitu pula dengan kadar retikulosit yang juga meningkat $(\mathrm{p}<0,001)$ setelah terapi. Hampir semua literatur menyebutkan bahwa dengan pemberian terapi besi yang adekuat, akan terjadi peningkatan kadar retikulosit dan Hb yang bermakna sebagai respon terhadap terapi yang diberikan. ${ }^{1,6,16,18,19}$ Berdasarkan hal tersebut, maka penelitian ini tidak membahas kenaikan kadar $\mathrm{Hb}$ dan retikulosit pada kelompok yang menerima besi saja melainkan pada kelompok yang menerima besi ditambah vitamin A dan seng.

Tampak perbedaan kadar $\mathrm{Hb}$ sebelum dan sesudah terapi pada kedua kelompok, $(p<0,01)$. Kadar Hb pada kelompok besi + vitamin A + seng meningkat lebih tinggi dibandingkan dengan kelompok besi saja, sedangkan retikulosit tidak berbeda bermakna $(p>0,05)$.

Pada populasi defisiensi mikronutrien sering terjadi bersamaan karena pola diet yang sama dan faktor sosio-ekonomi yang berhubungan dengan defisiensi mikronutrien. Di Indonesia, pada umumnya diet anak terdiri dari biji-bijian/padi-padian, rendah konsumsi daging, tinggi fitat sehingga berisiko tinggi terjadinya defisiensi mikronutrien, sehingga defisiensi besi, vitamin A dan seng sering terjadi. ${ }^{14,15,17}$

Interaksi antara seng dan besi dan vitamin A telah terbukti berpengaruh terhadap anemia pada tingkat metabolik. ${ }^{7}$ Seng berperan meningkatkan mekanisme pembentukan vitamin A melalui $R B P$ dan mekanisme langsungnya pada anemia, demikian pula vitamin A berperan dalam sintesis seng dan mekanisme langsungnya pada anemia, sehingga vitamin A dan seng dapat bekerja secara sinergis dan dapat memberikan efek yang positif terhadap terapi besi pada anemia..$^{2,7-10}$ Hal-hal tersebut dapat menjelaskan adanya kenaikan kadar $\mathrm{Hb}$ yang bermakna pada kelompok yang mendapat terapi besi 
+ vitamin A + seng dibandingkan pada kelompok yang hanya menerima preparat besi.

Retikulosit merupakan parameter yang umum digunakan untuk menilai keberhasilan terapi besi pada anemia defisiensi besi. Sebagai respon terhadap terapi besi, retikulosit akan meningkat dan kadarnya mencapai maksimal beberapa hari setelah terapi dan kemudian turun kembali ke keadaan normal. ${ }^{1,6,16}$ Sebagian literatur menyebutkan kadar maksimal tercapai pada hari ke 5-7 setelah terapi, namun ada pula juga yang menyebutkan pada hari ke-10 setelah terapi. ${ }^{1,16}$ Kenaikan kadar retikulosit sebagai respon terhadap terapi anemia defisiensi besi sangat kecil sekitar $12 \% .{ }^{19}$ Pada penelitian ini kadar retikulosit meningkat secara bermakna setelah mendapat terapi besi + vitamin A + seng, dibandingkan dengan sebelum terapi. Namun kenaikan kadar retikulosit antara kelompok besi + vitamin A + seng dengan kelompok besi tidak berbeda.

Uji kadar retikulosit pada penelitian ini tidak berbeda. Hal ini mungkin disebabkan masalah dalam teknik pengambilan sampel darah. Pengambilan sampel darah untuk pemeriksaan retikulosit tidak dapat dilakukan pada hari ke 5-7 dan 10 terapi oleh karena berbagai hal yang tidak dapat dihindari oleh peneliti, sehingga pengambilan sampel dilakukan pada hari ke-8 dan ke-9 terapi. Diduga pada ke-8 dan ke-9 tersebut kadar retikulosit sudah mulai turun kembali ke normal dari kadar maksimalnya (bila diduga kadar puncaknya pada hari ke 5-7) atau masih dalam keadaan normal (bila diduga kadar puncaknya pada hari ke-10). Diharapkan untuk penelitian lebih lanjut dapat di monitor pemeriksaan kadar retikulosit secara serial dari hari ke-5 hingga hari ke-10 terapi sehingga diketahui secara pasti saat retikulosit mencapai kadar maksimal dan hasil pada hari itulah yang seharusnya diukur dan dibandingkan sehingga hasil yang didapat secara statistik bermakna.

\section{Kesimpulan}

Kadar hemoglobin dan retikulosit meningkat sangat bermakna setelah mendapat terapi besi ditambah vitamin A dan seng. Terdapat peningkatan kadar hemoglobin yang bermakna pada kelompok besi + vitamin A + seng dibandingkan dengan kelompok besi. Tidak terdapat perbedaan yang bermakna pada peningkatan kadar retikulosit antara kedua kelompok.

\section{Daftar Pustaka}

1. Raspati H. Reniarti L. Susana S. Anemia defisiensi besi. Dalam: Permono HB, Sutaryo, Ugrasena IDG, Widiastuti E, Abdulsalam M, penyunting. Buku ajar Hematologi-Onkologi Anak. Jakarta: Badan Penerbit IDAI; 2005.h.30-43.

2. Mwanri L, Worsley A, Ryan P, Masika J. Supplemental vitamin A improves anemia and growth in anemic school children in Tanzania. Am J Clin Nutr 2000;10 : 2692-6.

3. Garcia MN, Layres M, Solano L.Vitamin A and beta carotene can improves non heme iron absorbstion from rice, wheat, and corn by human. Am J Clin Nutr 1997;14:646-50.

4. Dijkhuizen MA, Wieringa FT, West CE, Muherdiyantiningsih, Muhilal. Concurrent micronutrient deficiencies in lactating mothers and their infant in Indonesia. Am J Clin Nutr 2001;73:786-91.

5. Wardini S, Dewato H. Obat hematologik. Dalam: Ganiswarna $S$, penyunting. Farmakologi dan terapi; Edisi ke-4. Jakarta: FKUI; 1995.h.738-41.

6. Schwart E. Iron deficiency anemia. Dalam: Behrman RE, Kliegman RM, Jenson HB, penyunting. Nelson Textbooks of Pediatrics. Edisi ke-17. Philadelphia: Saunders; 2004.h.1614-6.

7. Alorwn K, Kolsteran PW, Prada AM. Effects of separate delivery of zinc or zinc and vitamin A on hemoglobin response, growth, and diarrhea in young Peruvian children receiving iron therapy for anemia. Am J Clin Nutr 2004;80:1276-82.

8. Rahman MM, Wohed M, Fucts GJ, Bogu, AH, Alverez JO. Synergistic effect of zinc and vitamin A on the biochemical indexes of vitamin A nutrition in children. Am J Clin Nutr 2002;75:92-8.

9. Munoz EC, Rosado Jl, Lopez P, Furr HC, Alen LH. Iron and zinc supplementation improves indicator of vitamin A status of Mexican preschoolers. Am J Clin Nutr 2000;71:789-94.

10. Christon P, West KP. Interaction between zinc and vitamin A : on update. Am J Clin Nutr 1998;76:805-12.

11. Zlotkin S. Arthur P. Schouerc. Home fortification with iron and zinc sprinkles or iron sprinkles alone successfully treats anemia in infants and young children. Am J Clin Nutr 2002;7 : 1076-80.

12. Dijkhuizen MA, Wieringga FT, West CE, Martuti S, Muhilal. Effects of iron and zinc supplementation in Indonesia infants on micronutrients status and growth. Am J Clin Nutr 2001:2861-5. 
13. Black M, Bagu AH, Zamank. Iron and zinc supplementation promote motor development and exploratory behavior among Banglades infants. Am J Clin Nutr 2004;80:903-10.

14. Whitsaker P. Iron and zinc interaction in humans. Am J Clin Nutrs 1998;65:4428-65.

15. Permono B, Ugrasena IDG. Anemia defisiensi besi pada anak. Continuing education ilmu kesehatan anak. Surabaya: FK UNAIR, 2002.h.55-68.

16. Dwipraharso I. Terapi anemia defisiensi besi berbasis bukti. Dalam: Triasi R, penyunting. Anemia defisiensi besi. Edisi pertama. Yogyakarta: FKUGM; 2005.h.6580 .

17. Freire WB. Hemoglobin as a predictor of respons to iron therapy and its use in screening and prevalence estimates. Am J Clin Nutr 1989;50:1442-9.

18. Abdulsalam M. Diagnosis, pengobatan dan pencegahan anemia defisiensi besi pada bayi dan anak. Dalam: Triasi $\mathrm{R}$, penyunting. Anemia defisiensi besi, edisi I. Yogyakarta: FKUGM; 2005.h.55-64.

19. Isbister JP, Pittiglio DH. Hematology clinic. Edisi I. Jakarta: Hipocrates, 1999:53-4. 